\title{
Mucopurulent cervicitis: a clinical entity?
}

\author{
F E WILLMOTT \\ From the Department of Genitourinary Medicine, Royal South Hants Hospital, Southampton
}

SUMMARY Of 297 women attending a sexually transmitted disease clinic who were examined for the presence of mucopurulent cervicitis, $96(32 \%)$ satisified the diagnostic criteria. Mucopurulent cervicitis was strongly associated with the isolation of Chlamydia trachomatis and Neisseria gonorrhoeae. It was also associated with bacterial vaginosis, the use of oral contraceptives, and sexual contact with men who had non-gonococcal urethritis.

Conversely, the presence of opaque cervical secretions did not show these associations, and the results indicated no difference in genital infections in women with clear cervical secretions whether or not more than 10 polymorphonuclear leucocytes per field (at a magnification of $\times 1000$ ) were present.

The findings support the suggestion that mucopurulent cervicitis is a definite clinical entity that requires investigation and treatment.

Non-gonococcal urethritis (NGU) is recognised by the presence of five or more polymorphonuclear leucocytes (PMNL) per field at a magnification of $\times 1000$ (high power field (HPF)) in a Gram stained smear.' The equivalent condition in women is termed non-specific genital infection (NSGI), but specific criteria for the diagnosis have not been defined. The clinical diagnosis of cervicitis is subjective, and differentiation between columnar cell ectopy (erosion) and cervicitis is difficult, if not impossible, with the naked eye. Cervicitis may be indicated by finding an excess of PMNL in a Gram stained smear of cervical secretions, but the number of polymorphs considered to be normal has not been defined. A condition of mucopurulent cervicitis has been described and designated the female equivalent of male NGU. ${ }^{2}$ The diagnosis of mucopurulent cervicitis is based on two findings: visible mucopurulent (yellow) cervical secretions, and more than $10 \mathrm{PMNL} / \mathrm{HPF}$ in the cervical secretions. Mucopurulent cervicitis has been associated particularly with the presence of Chlamydia trachomatis but not Neisseria gonorrhoeae or herpes simplex virus. ${ }^{2}$ Further studies have shown an association with Ureaplasma urealyticum, Gardnerella vaginalis, Trichomonas vaginalis, and the clinical diagnosis of bacterial vaginosis. ${ }^{3}$

The present study was undertaken to assess the presence of mucopurulent cervicitis in women attending a sexually transmitted diseases (STD) clinic in the United Kingdom and the validity of the definitive

Address for reprints: Dr F E Willmott, Department of Genitourinary Medicine, Royal South Hants Hospital, Graham Road, Southampton SO9 4PE

Accepted for publication 27 October 1987 criteria, particularly the importance of more than 10 PMNL/HPF in a Gram stained smear of the cervical secretions.

\section{Patients, materials, and methods}

Women attending the STD clinic of this hospital as new patients were studied. They were excluded if they were menstruating or if the cervical smear was not satisfactory (more than 100 squamous cells were present on the slide ${ }^{2}$ ). A routine history including details of contraceptive practice was taken. I examined all the patients as described by Brunham et $a l^{2}{ }^{2}$ and noted the presence of columnar cell ectopy or cervicitis (defined as erythema or oedema within the zone of ectopy), or both. The appearance of the cervical secretions was classified as mucopurulent (yellow), opaque (white or cloudy), or clear. The presence of any bleeding on swabbing the cervix was also recorded.

Endocervical mucus was collected with a cotton wool swab rolled on to a glass slide, which was Gram stained and examined under oil immersion at a $\times 1000$ magnification. A wet smear of vaginal secretions was examined for trichomonads, yeasts, and clue cells. Cultures for $\boldsymbol{N}$ gonorrhoeae were taken from the urethra and cervix on Transgrow medium (blood agar containing vancomycin, colistin, and nystatin). Vaginal secretions were transported in Amies' medium and cultured for Candida albicans on Sabouraud's medium. Material for culture for chlamydiae was taken from the cervix, placed in sucrose phosphate broth, and transported to the laboratory within four hours. It was then stored at $-70^{\circ} \mathrm{C}$ until the day of culture, which was performed twice weekly. The 
Table 1 Findings related to age of 297 women

\begin{tabular}{|c|c|c|c|}
\hline \multirow[b]{2}{*}{ Age } & \multicolumn{2}{|c|}{ No of women with: } & \multirow[b]{2}{*}{$\begin{array}{l}\text { No of } \\
\text { all women } \\
(n=297)\end{array}$} \\
\hline & $\begin{array}{l}\text { Mucopurulent } \\
\text { cervicitis } \\
(n=96)\end{array}$ & $\begin{array}{l}\text { Chlamydial } \\
\text { infection } \\
(n=57)\end{array}$ & \\
\hline $\begin{array}{l}\text { Under } 25 \\
\text { Over } 25\end{array}$ & $\begin{array}{l}64 \\
32\end{array}$ & $\begin{array}{l}46 \\
11\end{array}$ & $\begin{array}{l}172 \\
125\end{array}$ \\
\hline
\end{tabular}

specimens were cultured in BGMK (baboon green monkey kidney) cells inhibited by cycloheximide, and were examined by indirect immunofluorescence. A specimen for culture for herpes simplex virus was taken when appropriate. The diagnosis of bacterial vaginosis was made using the criteria of Amsel et al. ${ }^{4}$

\section{Results}

Of 297 women investigated, $96 \quad(32 \%)$ had mucopurulent, 57 (19\%) opaque, and $144(49 \%)$ clear cervical secretions. Gram stain of the cervical smears showed > 10 PMNL/HPF in all 96 with mucopurulent secretions, 55 out of 57 with opaque secretions, and 43 out of 144 with clear secretions. Induced cervical bleeding was present in 19 of all patients, but in 11 of the 96 women with mucopurulent cervicitis, eight of whom yielded chlamydiae. Clinical cervicitis was present in all 96 patients with mucopurulent secretions, in $38 / 57$ with opaque secretions, and in 5/144 with clear secretions.

\section{AGE}

Table 1 shows that patients aged under 25 made up $58 \%(172 / 297)$ of all patients, but $67 \%(64 / 96)$ of patients with mucopurulent cervicitis, which was a significant difference $\left(\chi^{2}=4.4 ; p<0.05\right)$.

\section{CONTRACEPTION}

Table 2 shows that $50 \%$ (149) of the women used oral contraceptives, $6 \%$ (18) used intrauterine contraceptive devices (IUCDs), 9\% (27) used a barrier method (sheath or diaphragm), and $35 \%$ (104) used no contraception. Of the 96 women with mucopurulent cervicitis, $69(72 \%)$ used oral contraceptives $\left(\chi^{2}=\right.$ 26.7; $\mathrm{p}<0.001)$.
Table 2 Methods of contraception used by 297 women

\begin{tabular}{llllll}
\hline $\begin{array}{lllll}\text { Appearance } \\
\text { of cervical } \\
\text { mucus }\end{array}$ & \multicolumn{2}{l}{ No using: } & & \\
\cline { 2 - 5 } & Oral & IUCD & Barrier & None & Total \\
\hline Mucopurulent & 69 & 5 & 4 & 18 & 96 \\
Opaque & 29 & 6 & 3 & 19 & 57 \\
Clear & 51 & 7 & 20 & 66 & 144 \\
Total & 149 & 18 & 27 & 103 & 297 \\
\hline
\end{tabular}

IUCD = intrauterine contraceptive device.

\section{MENSTRUAL CYCLE}

The type of cervical mucus was related to the time of the last menstrual period (35 patients with amenorrhoea of more than four weeks' duration were excluded). It was classified as postmenstrual (proliferative), mid-cycle (ovulatory), or premenstrual (secretory). Table 3 shows that mucopurulent, opaque, or clear secretions containing more than 10 PMNL/HPF were not associated with any phase of the menstrual cycle. The presence of clear mucus containing fewer than $10 \mathrm{PMNL} / \mathrm{HPF}$ appeared to be most common in the mid-cycle phase, but this was not significant. $^{2}$

\section{ASSOCIATED INFECTIONS}

Cervical infections with $N$ gonorrhoeae, chlamydiae, or herpes simplex virus were present in 54 women with mucopurulent, 15 with opaque, and 27 with clear mucus. Table 4 shows the incidence of individual infections. Mucopurulent cervicitis was significantly associated with gonorrhoea $\left(\chi^{2}=23.6\right.$; $\left.\mathrm{p}<0.001\right)$, chlamydial infection $\left(\chi^{2}=34.2 ; \mathrm{p}<0.001\right)$, and bacterial vaginosis $\left(\chi^{2}=56\right.$; $\left.\mathrm{p}<0.02\right)$, but was negatively associated with candidiasis. Opaque secretions were not associated with any particular infection.

SEXUAL CONTACTS OF MEN WITH NGU

Table 5 shows that of 77 women who were known sexual contacts of men with NGU, 27 yielded chlamydiae and 41 had mucopurulent cervicitis.

\section{EFFECT OF TREATMENT}

Of 43 women with mucopurulent cervicitis but without gonorrhoea or chlamydial infection who received tetracyclines or erythromycin, 28 attended follow up and 19 of them showed resolution of the mucopurulent cervicitis.

Table 3 Cervical mucus related to menses in 262 women

\begin{tabular}{|c|c|c|c|c|}
\hline \multirow[b]{2}{*}{ Phase of cycle } & \multirow{2}{*}{$\begin{array}{l}\text { Mucopurulent mucus } \\
(n=88)\end{array}$} & \multirow{2}{*}{$\begin{array}{l}\text { Opaque mucus } \\
(n=52)\end{array}$} & \multicolumn{2}{|c|}{ Clear mucus $(n=122)$} \\
\hline & & & $>10 P M N L / H P F$ & $<10 P M N L / H P F$ \\
\hline $\begin{array}{l}\text { Postmenstrual } \\
\text { Mid-cycle } \\
\text { Premenstrual }\end{array}$ & $\begin{array}{l}28 \\
28 \\
32\end{array}$ & $\begin{array}{l}19 \\
15 \\
18\end{array}$ & $\begin{array}{l}10 \\
14 \\
14\end{array}$ & $\begin{array}{l}26 \\
38 \\
20\end{array}$ \\
\hline
\end{tabular}

PMNL = polymorphonuclear leucocytes; HPF $=$ high power $(\times 1000$ magnification $)$ field. 
Table 4 Associated infections in 297 women

\begin{tabular}{|c|c|c|c|c|c|}
\hline \multirow[b]{2}{*}{ Cervical infections } & \multirow{2}{*}{$\begin{array}{l}\text { Mucopurulent } \\
\text { mucus } \\
(n=96)\end{array}$} & \multirow{2}{*}{$\begin{array}{l}\text { Opaque } \\
\text { mucus } \\
(n=57)\end{array}$} & \multicolumn{2}{|l|}{ Clear mucus } & \multirow[b]{2}{*}{$\begin{array}{l}\text { Total } \\
(n=297)\end{array}$} \\
\hline & & & $\begin{array}{l}>10 P M N L / H P F \\
(n=43)\end{array}$ & $\begin{array}{l}<10 P M N L / H P F \\
(n=101)\end{array}$ & \\
\hline Gonorrhoea & 20 & 3 & 1 & 3 & 27 \\
\hline Chlamydial infection & 36 & 10 & 4 & 7 & 57 \\
\hline Herpes simplex virus & 7 & 4 & 4 & 9 & 24 \\
\hline Candidiasis & 17 & 17 & 14 & 30 & 78 \\
\hline Bacterial vaginosis & 40 & 17 & 9 & 30 & 96 \\
\hline Trichomoniasis & 8 & 5 & 2 & 3 & 18 \\
\hline Warts & 11 & 6 & 8 & 13 & 38 \\
\hline
\end{tabular}

Table 5 Chlamydial infection in 77 female sexual contacts of men with non-gonococcal urethritis (NGU) correlated with appearance of cervical mucus

No of NGU contacts

\begin{tabular}{lll}
$\begin{array}{l}\text { Appearance of } \\
\text { cervical mucus }\end{array}$ & $\begin{array}{l}\text { Chlamydia } \\
\text { negative } \\
(n=50)\end{array}$ & $\begin{array}{l}\text { Chlamydia } \\
\text { positive } \\
(n=27)\end{array}$ \\
\hline Mucopurulent $(\mathrm{n}=41)$ & 22 & 19 \\
Opaque $(\mathrm{n}=16)$ & 12 & 4 \\
Clear $(\mathrm{n}=20)$ & 16 & 4 \\
\hline
\end{tabular}

\section{Discussion}

The object of the study was to assess the importance of the physical appearance of the cervical mucus and of the presence of more than 10 PMNL/HPF in a Gram stained smear of the mucus. In this series $32 \%$ of women attending an STD clinic had mucopurulent secretions. Mucopurulent cervicitis was positively associated with the presence of chlamydiae, as shown in previous studies, ${ }^{23}$ but I know of no previous study showing an association with gonorrhoea. Bacterial vaginosis was also associated with mucopurulent cervicitis, even when patients with chlamydial infection and gonorrhoea were excluded. As bacterial vaginosis does not cause vaginitis, it is unlikely to cause cervicitis unless it has a specific effect on columnar epithelium. The cause of the cervicitis is not known, but the effect is probably damage to the epithelium that produces an environment favouring the growth of anaerobes, as suggested by Masfari et $a l^{5}$ In contrast to other workers, I found no association between $T$ vaginalis and mucopurulent cervicitis. As described previously, ${ }^{23} \mathrm{C}$ albicans was negatively associated with mucopurulent cervicitis. The use of oral contraceptives was associated with mucopurulent cervicitis, particularly if chlamydiae were present, but not if gonorrhoea was present.

Mucopurulent cervicitis has been described as the equivalent in women of NGU in men. Of the 77 women who were known sexual contacts of men with NGU, 41 had mucopurulent cervicitis and 27 had chlamydial infection. The response to tetracyclines or erythromycin in $68 \%(19 / 28)$ of the non-chlamydial non-gonococcal group compares with the success of treatment of non-chlamydial NGU in men.

Opaque cervical secretions were not associated with any infections or any phase of the menstrual cycle. Clear cervical secretions were negatively associated with chlamydial infection and gonorrhoea. Brunham et al used 10 PMNL/HPF as the diagnostic criterion for cervicitis. ${ }^{2}$ Other studies have used a different number of polymorphs as indicative of cervicitis, for example Fox used the arbitrary figure of $50 \mathrm{PMNL} /$ HPF. ${ }^{6}$ All patients with mucopurulent mucus had more than $10 \mathrm{PMNL} / \mathrm{HPF}$, as did $96 \%$ (55/57) of those with opaque mucus. In the group with clear mucus, however, those with more than 10 PMNL/ HPF had no more genital infections than those with fewer than 10 PMNL/HPF, and 7\% (3/43) and 12\% $(12 / 101)$ of the two groups were sexual contacts of men with NGU. Further studies are required to assess the number of polymorphs that indicate cervicitis. A more accurate method of assessing the numbers is probably also required.

This study shows that mucopurulent cervicitis is a definite entity that can be diagnosed clinically by the presence of mucopurulent (yellow) cervical mucus, and diagnosis does not depend on the results of a Gram stained smear. As the presence of mucopurulent cervicitis is an indicator of gonorrhoea or chlamydial or non-specific genital infection in most cases, the treatment given should be effective against all these conditions if culture facilities are not available. The male sexual contacts of women with mucopurulent cervicitis should also be traced and examined.

\section{References}

1 Swartz SL, Kraus SJ, Harman KL, Stargel MD, Brown WJ, Allen SD. Diagnosis and etiology of nongonococcal urethritis. $J$ Infect Dis 1978;138:445-54.

2 Brunham RC, Paavonen J, Stevens CE, et al. Mucopurulent cervicitis-the ignored counterpart in women of urethritis in men. $N$ Engl J Med 1984;311:1-6.

3 Paavonen J, Critchlow CW, Rouen T, et al. Etiology of cervical inflammation. Am J Obstet Gynecol 1986;154:556-64.

4 Amsel R, Totten PA, Spiegel CA, Chen KCS, Eschenbach D, Holmes KK. Non-specific vaginitis: diagnostic criteria and microbial and epidemiologic associations. Am J Med 1983;74:14-22.

5 Masfari AN, Duerden BI, Kinghorn GI. Quantitative studies of vaginal bacteria. Genitourin Med 1986;62:256-63.

6 Fox H. Non-specific genital infection in a general practice. British Journal of Venereal Diseases 1974;50:125-31. 